\title{
Facultative Wood-digesting Bacteria from the Hind-gut of the Termite Reticulitermes hesperus
}

\author{
By D. W. THAYER \\ Department of Biological Sciences, Texas Tech University, \\ Lubbock, Texas 79409, U.S.A. \\ (Received 1o November 1975; revised I6 January 1976)
}

\begin{abstract}
SUMMARY
Among the facultative bacteria capable of growth on mesquite wood which were isolated from the asceptically dissected hind-gut of the termite Reticulitermes hesperus were two strains of Bacillus cereus, one strain each of Arthrobacter, Alcaligenes and Serratia, and a very small Gram-negative fermentative rod. The B. cereus strains, the Serratia marcescens strain and the Arthrobacter sp. grew well on a mineral salts $\alpha$-cellulose agar. One of the Bacillus cereus strains and Serratia marcescens hydrolysed gels of carboxymethylcellulose. All isolates grew well with mesquite wood as the carbon source. The Serratia marcescens isolate produced prodigiosin but differed from a typed strain both in size and in some physiological characteristics.
\end{abstract}

\section{INTRODUCTION}

Mesquite brush (genus Prosopis) cannot be digested by cattle in its native form, but aerobic, submerged cultivation of bacteria on the mesquite wood increases the digestible protein and exposes the wood structure to the digestive processes of the ruminant (Thayer et al., 1975). Many sources of bacteria were considered for this process, including the hindgut of the termite. Since wood contains many possible substrates, bacteria capable of utilizing mesquite as their carbon and energy source would not necessarily be cellulolytic.

Several species of bacteria which grew rapidly on media containing mesquite wood as the carbon source were isolated from the hind-gut of the termite. One of these species, designated Serratia marcescens RW3, was used in the laboratory for production of single-cell protein (Thayer et al., I975). This strain and others isolated from the hind-gut possess cellulolytic enzymes (Thayer et al., I975). In view of their possible commercial application a more detailed study of these bacteria seemed justified. This paper describes the physiological and morphological properties of strains of bacteria isolated from the hind-gut of the termite.

\section{METHODS}

Reticulitermes hesperus was isolated from infested wood in Oklahoma and Texas. Hindguts were dissected aseptically from worker termites which had been washed in Wescodyne antiseptic (West Chemical Products, New York, New York I I Ior, U.S.A.; U.S. pat. no. $2710277)$ and then in sterile water to suppress surface bacteria. Samples (0.01 and $0.04 \mathrm{ml}$ ) of the hind-gut contents were mixed with physiological saline $(0.35$ or $1 \cdot 95 \mathrm{ml}$, respectively), and spread plates were prepared on BBL Trypticase soy agar (TSA). Cultures were incubated at $30^{\circ} \mathrm{C}$ until maximum colony development had occurred. Each colony type was 
restreaked several times in sequence on TSA to obtain pure cultures. They were characterized by the following methods.

Morphological characteristics. Bacterial form, size, pleomorphism and Gram-stain reaction were determined with bacteria grown on TSA, BBL Trypticase soy broth (TSB), or TSA containing I \% (w/v) glucose. Motility was investigated by hanging-drop flagellation confirmed by staining (Leifson, I95I). Metachromatic granules were observed in bacteria grown on TSA plus glucose for $24 \mathrm{~h}$ by the staining method of Skerman (1967), and fuchsin stains were prepared by the technique of Smith, Gordon \& Clark (1952).

Cultural characteristics. Growth, surface structure, pigmentation, etc. were observed after I to Io days incubation on TSA, nutrient agar, or TSA plus $1 \%(w / v)$ glucose. Basal media, pH 7.0, contained (g/l distilled water): $\mathrm{NaCl}, 3 \cdot 0 ; \mathrm{KH}_{2} \mathrm{PO}_{4}, \mathrm{I} \cdot 0 ; \mathrm{K}_{2} \mathrm{HPO}_{4}, \mathrm{I} \cdot 0 ; \mathrm{MgSO}_{4}$, $0.05 ; \mathrm{CaCl}_{2}, 0.05$; special Noble Agar (Difco), 20.0; and either carboxymethylcellulose, I0.0; or $\alpha$-cellulose, I0.0; or Cellex MN (BioRad Laboratories, Richmond, California 94804, U.S.A.), microcrystalline cellulose, 0.5 ; or Cellex MN, 0.5, and yeast extract, 0.5 . The media were sterilized by autoclaving for $\mathrm{I} 5 \mathrm{~min}$ at $\mathrm{I} 2 \mathrm{I}{ }^{\circ} \mathrm{C}$ and poured into Petri plates.

Biochemical characteristics. Fermentative abilities were determined in phenol red broth base (Difco) or bromothymol blue broth base (Difco) containing filter-sterilized carbohydrate $\left(5^{\circ} \circ \mathrm{g}^{-1}\right)$. The type of glucose, lactose and sucrose cleavage was determined by the Hugh \& Leifson (1953) method. Glucose and xylose fermentation were rechecked on slants by the technique of Gibson \& Gordon (1974). Cultures were incubated at $35^{\circ} \mathrm{C}$ for $2 \mathrm{I}$ days.

Organic acid assimilation was tested by using a modified Christensen's medium (Yamada \& Komagata, 1972). Cultures were incubated at $35^{\circ} \mathrm{C}$ for 2I days. A change in the $\mathrm{pH}$ from neutral to alkaline was considered a positive result. Uninoculated controls were incubated under identical conditions. Organic acids or carbohydrate assimilation, as sole carbon source, was assayed with the Stanier, Palleroni \& Doudoroff (1966) medium. Assimilation was indicated by growth and a change in the $\mathrm{pH}$ of the medium, provided that the culture retained viability upon transfer to the same medium at $35^{\circ} \mathrm{C}$.

Extracellular deoxyribonuclease (DNAase) was detected with DNAase test medium (Difco) after abundant growth had occurred at $35{ }^{\circ} \mathrm{C}$. Urease was detected with urea broth (Difco). Cellulolytic activity was tested with a filter paper strip-peptone medium (Skerman, 1967). Casein hydrolysis was determined after growing the culture on a medium containing $20 \mathrm{ml}$ skim milk, autoclaved for $\mathrm{Io}$ min at $\mathrm{II} 4{ }^{\circ} \mathrm{C}$, per $\mathrm{ml} \mathrm{TSA}$. Pectinase was detected using sodium polypectate with TSA as a basal medium (Skerman, 1967). Peroxidase was determined by the Anderson (1930) procedure. Dihydroxyacetone production from glycerol was determined according to Shimwell, Carr \& Rhodes (1960). Hydrolysis of carboxymethylcellulose (CM-cellulose) was detected by the liquefaction of a gel containing ( $\mathrm{g} / \mathrm{l}$ distilled water): sodium carboxymethylcellulose (type $7 \mathrm{H}$; Hercules Inc., Wilmington, Delaware, U.S.A.), 20.0; $\mathrm{NaCl}, 3.0 ;\left(\mathrm{NH}_{4}\right)_{2} \mathrm{SO}_{4}, 8.0 ; \mathrm{KH}_{2} \mathrm{PO}_{4}, \mathrm{I} \cdot 0 ; \mathrm{K}_{2} \mathrm{HPO}_{4}, \mathrm{I} \cdot 0 ; \mathrm{MgSO}_{4}, 0.05$; $\mathrm{CaCl}_{2}, 0.05$; Casamino acids (Difco), 0.50 . The $\mathrm{pH}$ was adjusted to 6.5 and $\mathrm{Io} \mathrm{ml}$ portions of the medium were placed in I6 $\times$ I50 $\mathrm{mm}$ test-tubes. Duplicate tubes were inoculated by stabbing, and incubated for $2 \mathrm{I}$ days. In the presence of carboxymethylcellulase, the gel was hydrolysed to a water-like viscosity. Uninoculated controls were always included.

Other tests for phospholipase and lipase activity, nitrate reduction, indole production, phenylalanine deaminase, L-lysine decarboxylase, L-arginine decarboxylase, L-ornithine decarboxylase, methyl red and Voges-Proskauer reactions, and $\alpha$-amylase were tested according to Holding \& Collee (I97I), and tyrosinase by the disappearance of crystals of L-tyrosine $(0.5 \%)$ in nutrient agar (Gordon, Haynes \& Pang, 1973).

Prodigiosin was extracted and purified according to the alkaline extraction procedure of 
Hubbard \& Rimington (1950) using Serratia marcescens Nima as a control (Williams et al., 1971). Water-soluble pigment(s) were extracted from 5-day-old surface-grown Serratia marcescens Nima and $S$. marcescens RW 3 by suspending bacteria in distilled water and then centrifuging for $30 \mathrm{~min}$ at $10000 \mathrm{~g}$. Extracts were filtered through a $0.2 \mu \mathrm{m}$ membrane filter which removed most of the pigment from the former extract but not from the latter. Alcohol-soluble pigment(s) were extracted from intact bacteria in a similar way using absolute ethanol, and clarifying the suspensions by centrifuging at $10000 \mathrm{~g}$. Spectra were obtained with a Perkin Elmer Model 402 double-beam recording spectrophotometer with a path length of $\mathrm{I} \mathrm{cm}$.

Physiological characteristics. The effect of $\mathrm{NaCl}$ on growth in TSB containing $\mathrm{NaCl}$ at $0.5,5.0,7.0,10 \cdot 0$, and $15.0 \%(\mathrm{w} / \mathrm{v})$ was determined at $30^{\circ} \mathrm{C}$. Nutritional requirements were determined using media based on those of Knight \& Proom (1950). Ammonia basal medium consisted of $\left(\mathrm{g} \mathrm{l}^{-1}\right)$ : $\mathrm{KH}_{2} \mathrm{PO}_{4}, \mathrm{I} \cdot 5 ;\left(\mathrm{NH}_{4}\right)_{2} \mathrm{HPO}_{4}, 7 \cdot 0 ; \mathrm{MgSO}_{4} \cdot 7 \mathrm{H}_{2} \mathrm{O}, 0 \cdot 5 ; \mathrm{CaCl}_{2}$. $2 \mathrm{H}_{2} \mathrm{O}, 0.3 ; \mathrm{MnSO}_{4} .4 \mathrm{H}_{2} \mathrm{O}, 0.04 ; \mathrm{FeSO}_{4} \cdot 7 \mathrm{H}_{2} \mathrm{O}, 0.0025$; glucose, 10.0. Basal salts-casein hydrolysate medium consisted of basal salts medium plus $4.0 \mathrm{~g}$ vitamin-free Casamino acids (Difco). Basal salts-yeast extract medium consisted of basal salts medium plus $\mathrm{I} \cdot 0 \mathrm{~g}$ of yeast extract (Difco). Basal salts-casein hydrolysate-yeast extract medium included both yeast extract and Casamino acids in the concentrations given above. Other media were medium 7AA and medium I4AA of Knight \& Proom (1950). All media were sterilized by filtration. Bacteria were grown in TSB at $30{ }^{\circ} \mathrm{C}$, centrifuged and washed twice in sterile physiological saline. Two portions of each medium $(5 \mathrm{ml})$ were inoculated with $0.05 \mathrm{ml}$ washed bacteria suspended in their original volume of physiological saline. If growth occurred, a loopful was used to inoculate another tube of the same medium. The test was considered positive only when the culture remained viable upon transfer to the same medium. Sensitivity to antibiotics and other agents was determined using the sensitivity disc (Difco) technique. The filter-paper discs were placed on inoculated TSA plates and the zones of inhibition measured after $48 \mathrm{~h}$ incubation at $35^{\circ} \mathrm{C}$.

All cultures were incubated at $35^{\circ} \mathrm{C}$ unless otherwise indicated. All tests were performed in duplicate.

\section{RESULTS}

The bacterial flora, which grew well on ordinary culture media, of the hind-gut of the termite was consistent in both relative numbers and types. The same species of bacteria were isolated over a period of several months from dissected hind-guts of many termites obtained from both the Texas and Oklahoma colonies. Seven different bacteria were isolated and designated RWI to RW7. Organism RW4 was not isolated consistently from hindguts and so was not studied further. The biochemical and physiological characteristics of the others are given in Tables I to 5. Preliminary characterization of these strains indicated that there were two strains of Bacillus, one strain each of Arthrobacter, Alcaligenes and Serratia, and a very small fermentative Gram-negative rod designated Rw2. The Serratia species was present in the fewest numbers, usually less than $3 \%$ of the total colonies. Strain RW2 usually represented about $\mathrm{I} 4 \%$ of the total colonies, and RWI, RW5, RW6 and RW7 were about equally represented.

Strain RW2 grew very slowly on TSA or other culture media and formed colonies which remained minute after several days' incubation. The organism was a motile Gram-negative coccus, $0.3 \mathrm{I}$ by $0.3 \mathrm{I} \mu \mathrm{m}$, usually in pairs, which rarely separated and might therefore be a bipolar staining cell, $0.3 \mathrm{I}$ by $0.62 \mu \mathrm{m}$. The organism was penicillin resistant. It could not be classified using Bergey's Manual of Determinative Bacteriology (1974); though two genera 
Table. I. Morphological and biochemical characteristics of bacteria isolated from termites

Character

Cell morphology

Gram reaction

Endospores

Motility

Metachromatic granules

Growth

KCN broth

$\mathrm{TSB}+5.5 \%(\mathrm{w} / \mathrm{v}) \mathrm{NaCl}$

$\mathrm{TSB}+7.0 \%(\mathrm{w} / \mathrm{v}) \mathrm{NaCl}$

TSB $+10.0 \%(w / v) ~ N a C l$

In presence of lysozyme

At $\mathrm{pH} 7$, at $60^{\circ} \mathrm{C}$

At pH 6, at $60^{\circ} \mathrm{C}$

At pH 5.7 , at $30^{\circ} \mathrm{C}$

On $\alpha$-cellulose agar

On CM-cellulose agar

On microcrystalline cellulose agar

On microcrystalline cellulose

agar + yeast extract

Anaerobic in Brewer's thioglycollate

Biochemical tests

Gelatin hydrolysis

Casein hydrolysis

Urea hydrolysis

Tryptophan hydrolysis

Lipid hydrolysis

Lecithin hydrolysis

Amylose hydrolysis

Pectin hydrolysis

CM-cellulose gel hydrolysis

DNA hydrolysis

Methyl red test

Acetoin production

Catalase

Cytochrome oxidase

Peroxidase

Phenylalanine deaminase

L-Lysine decarboxylase

L-Arginine decarboxylase

L-Ornithine decarboxylase

Nitrate reduction

Tyrosine decomposition

Pigment production in presence

of $0.01 \%$ tyrosine

Dihydroxyacetone production $\begin{array}{lllll}\text { RWI } & \text { RW2 } & \text { RW3 } & \text { RW5 } & \text { RW6 }\end{array}$

Rw7 Nima $\dagger$

+ , Positive; -, negative; \pm , doubtful. NG, no growth occurred; NT, not tested.

* Weak positive reaction below growth.

$\uparrow$ Serratia marcescens Nima included as reference strain.

appeared somewhat similar, Escherichia and Wolbachia. Because of its very slow growth, RW2 was not of commercial interest and was not included in further studies.

Strain Rw5, identified as a probable Alcaligenes species, was a Gram-negative rod, 0.64 by $\mathrm{I} \cdot 28 \mu \mathrm{m}$. Its metabolism was oxidative (Table 2 ), and it utilized citrate.

Strains RWI and RW7 were both Bacillus cereus but differed in a number of characters. 
Table 2. Acid formation from carbohydrates

RW6 did not form acid from carbohydrates.

\begin{tabular}{|c|c|c|c|c|c|c|}
\hline Carbohydrate & RWI & RW2 & RW3 & RW5 & RW7 & Nima $†$ \\
\hline \multicolumn{7}{|c|}{ Bromothymol blue or phenol red broth base* } \\
\hline L-Arabinose & - & + & - & - & - & - \\
\hline D-Xylose & - & + & - & + & - & - \\
\hline Rhamnose & - & + & - & - & - & - \\
\hline D-Glucose & + & +o & + & + & + & + \\
\hline D-Fructose & + & + & + & - & + & + \\
\hline D-Mannose & - & + & + & - & - & + \\
\hline D-Galactose & - & + & + & + & - & - \\
\hline Sucrose & + & + & + & - & + & + \\
\hline Lactose & - & + & - & - & - & - \\
\hline Maltose & + & + & + & - & + & + \\
\hline Trehalose & + & NT & + & NT & + & + \\
\hline$\beta$-D-Cellobiose & + & NT & - & NT & - & - \\
\hline Raffinose & - & + & - & - & - & - \\
\hline Melezitose & - & NT & - & NT & - & - \\
\hline Dextrin & - & NT & - & NT & - & - \\
\hline Starch & + & NT & - & NT & - & - \\
\hline Inulin & - & + & - & - & - & - \\
\hline Glycerol & + & - & + & - & + & + \\
\hline Adonitol & - & NT & - & NT & - & - \\
\hline Mannitol & - & NT & + & NT & - & + \\
\hline Dulcitol & - & NT & - & NT & - & - \\
\hline Sorbitol & - & NT & - & NT & - & + \\
\hline Inositol & - & NT & - & NT & - & + \\
\hline Aesculin & + & NT & + & NT & - & + \\
\hline Salicin & + & NT & + & NT & - & + \\
\hline Melibiose & - & NT & - & NT & - & - \\
\hline \multicolumn{7}{|l|}{ Hugh \& Leifson media } \\
\hline Glucose, aerobic & - & + & + & - & - & + \\
\hline Glucose, anaerobic & - & + & + & - & - & + \\
\hline Sucrose, aerobic & - & NT & + & NT & - & NT \\
\hline Sucrose, anaerobic & - & NT & + & NT & - & NT \\
\hline Lactose, aerobic & - & NT & - & NT & - & NT \\
\hline Lactose, anaerobic & - & NT & - & NT & - & NT \\
\hline Glucose broth, aerobic & \pm & NT & + & NT & + & NT \\
\hline Glucose broth, anaerobic & \pm & NT & + & NT & + & NT \\
\hline Gordon glucose slants & $\bar{t}$ & NT & + & NT & + & + \\
\hline Gordon glucose stabs & + & NT & + & NT & + & + \\
\hline & - & NT & NT & NT & - & \\
\hline
\end{tabular}

- , Acid not produced; + , acid produced; +0 , acid and gas produced; $N T$, not tested.

* Acid formation by strains RWI, RW3, RW6, RW7, and Nima was determined in bromothymol blue broth base. Acid formation by strains RW2 and RW5 was determined in phenol red broth base.

$\dagger$ Serratia marcescens Nima included as reference strain.

Strain RWI was a large, Gram-positive, endospore-forming, facultatively anaerobic rod, being 0.86 by $2.26 \mu \mathrm{m}$ with round ends and not swollen by the cylindrical subterminal endospores. Cells grown on nutrient agar containing I \% glucose showed unstained areas when lightly stained or when stained with basic fuchsin. Metachromatic granules were observed at each end of the cell. Those bacteria which were peritrichously flagellated were highly motile in hanging drops. Colonies on TSA after 5 days' incubation at $30^{\circ} \mathrm{C}$ were 4 to $5 \mathrm{~mm}$ diam., rough-surfaced, lobate-edged, flat, opaque, and off-white in colour. It grew well on mineral salts medium containing I $\%(w / v) \alpha$-cellulose and could be transferred on the same medium, but grew poorly on the same basal salts medium containing I $\%$ 
Table 3. Assimilation of organic acids

All strains used formic, acetic, pyruvic, lactic, and succinic acid; none used adipic, glycollic, or uric acid.

Acid

Malic acid

Fumaric acid

$\alpha$-Ketoglutaric acid

Citric acid

Propionic acid

Oxalic acid

Malonic acid

Glutaric acid

Pimelic acid

Hippuric acid

$\begin{array}{ccccc}\text { RWI } & \text { RW3 } & \text { RW6 } & \text { RW7 } & \text { Nima* } \\ + & + & - & + & + \\ + & + & \pm & + & + \\ + & + & - & + & + \\ - & + & + & + & + \\ - & + & - & + & + \\ + & + & + & + & \text { NT } \\ + & + & - & + & + \\ - & \text { NT } & - & - & \text { NT } \\ - & + & + & - & + \\ + & + & \text { NT } & + & +\end{array}$

NT, Not tested.

* Serratia marcescens Nima included as reference strain.

\section{Table 4. Assimilation of compounds as sole carbon source}

None of the organisms used propionic, butyric, glycollic, hippuric, uric, tartaric, adipic, or oxalic acids, nor xylose, lactose, cellobiose, $\alpha$-amylose, or $\alpha$-cellulose as sole carbon sources. Strains RW6 and Rw7 could not assimilate any of the compounds listed as sole carbon sources.

$\begin{array}{lccclccc}\text { Organic acid } & \text { RWI } & \text { RW3 } & \text { Nima* } & \text { Carbohydrate } & \text { RWI } & \text { Rw3 } & \text { Nima* } \\ \text { Acetic acid } & - & + & - & \text { Glucose } & - & + & + \\ \text { Pyruvic acid } & - & + & + & \text { Fructose } & - & + & - \\ \text { Lactic acid } & - & + & + & \text { Galactose } & - & + & + \\ \text { Malic acid } & + & + & + & \text { Sucrose } & - & + & + \\ \text { Succinic acid } & - & + & + & \text { Maltose } & - & + & + \\ \text { Fumaric acid } & + & + & + & \text { Mannitol } & & + \\ \text { Citric acid } & - & + & + & & & \\ \text { Formic acid } & - & + & + & & \\ \text { Malonic acid } & - & - & + & \end{array}$

(w/v) CM-cellulose. Poor growth occurred on agar containing microcrystalline cellulose in the absense of yeast extract, and clear zones did not develop around the colonies. CMcellulose gel was rapidly hydrolysed from the surface downwards (Table I). Growth on nutrient agar slants incubated for $24 \mathrm{~h}$ at $30^{\circ} \mathrm{C}$ was echinate, white and translucent. The presence of I \% glucose in the nutrient agar gave dry, rough, creamy colonies. Abundant growth occurred on potato dextrose agar (Difco). Anaerobic growth occurred in motility test agar and in Brewer's thioglycollate medium (Difco). Abundant growth occurred upon transfer to basal salts medium containing either Casamino acids, yeast extract or both. A very active phospholipase was secreted from the culture. A $\mathrm{r} \mathrm{cm}$ wide opaque zone and a small but distinct transparent zone at the edge of the colony developed after 4 days' incubation. Other data are presented in Tables $\mathrm{I}$ to 5 .

Strain RW7, also Bacillus cereus, was a large Gram-positive, endospore-forming, facultatively anaerobic rod, with rounded ends, being I by $4^{\circ} 0 \mu \mathrm{m}$ when grown on TSA for $24 \mathrm{~h}$ at $30{ }^{\circ} \mathrm{C}$. Cells grown on nutrient agar containing $\mathrm{I} \%(\mathrm{w} / \mathrm{v})$ glucose stained unevenly with Gram stain or fuchsin. Metachromatic granules were present. Lipid accumulations were demonstrated by staining with Sudan black B. Endospores were cylindrical, completely 
Table 5. Antibiotic sensitivity

$\begin{array}{lcccc}\text { Antibiotic } & \text { RWI } & \text { RW3 } & \text { RW6 } & \text { RW7 } \\ \text { Bacitracin (I0 u.) } & - & - & ++ & \pm \\ \text { Dihydrostreptomycin (Io } \mu \mathrm{g}) & + & - & ++ & ++ \\ \text { Erythromycin }(50 \mu \mathrm{g}) & ++ & - & ++ & ++ \\ \text { Erythromycin }(150 \mu \mathrm{g}) & ++ & - & ++ & ++ \\ \text { Furadantin }(\mathrm{I} \cdot 5 \mathrm{mg}) & ++ & + & ++ & ++ \\ \text { Kanamycin }(100 \mu \mathrm{g}) & ++ & + & ++ & + \\ \text { Nalidixic acid }(100 \mu \mathrm{g}) & ++ & ++ & + & ++ \\ \text { Neomycin }(100 \mu \mathrm{g}) & ++ & + & ++ & ++ \\ \text { Penicillin G (5 } \mathrm{u} .) & - & - & ++ & \pm \\ \text { Penicillin G (10 u.) } & - & - & ++ & + \\ \text { Streptomycin }(100 \mu \mathrm{g}) & ++ & \pm & ++ & ++ \\ \text { Sulphathiazole }(3 \mathrm{mg}) & + & - & - & \pm \\ \text { Tetracycline }(100 \mu \mathrm{g}) & ++ & - & ++ & ++\end{array}$

- , No zone of inhibition; \pm , small zone of inhibition; + , moderate zone of inhibition; ++ , large zone of inhibition.

filling the sporangium; in a few cases, the sporangium appeared swollen. The cells, when motile, were peritrichous though most cells were immotile. Surface colonies on TSA were irregular, approximately $3 \mathrm{~mm}$ diam. after 5 days' growth at $30^{\circ} \mathrm{C}$, umbonate, dullsurfaced, erose-edged, white, opaque, and butyraceous. There was abundant opaque, offwhite growth on TSA slants with a raised elevation, rough surface, and erose edge. Abundant flocculent growth occurred in TSB, with a ring formation at the surface. No growth occurred on potato dextrose agar. Cells grew anaerobically in motility test medium and Brewer's thioglycollate medium (Difco). Abundant growth occurred on mineral salts agar containing I $\%(\mathrm{w} / \mathrm{v}) \alpha$-cellulose or CM-cellulose. The phospholipase activity was very similar to that of strain RWI. Nutritional requirements appeared to be identical to those of RWI.

Organism RW3 was a strain of Serratia and as Sakazaki (1974) recognized only one species in this genus, Serratia marcescens, RW 3 is so identified. For this reason a comparison culture of Serratia marcescens Nima (Williams et al., I97I) was included in this study.

Serratia marcescens RW3 cells were typical of the genus, i.e. very small Gram-negative rods $0.5 \mathrm{I}$ by $0.79 \mu \mathrm{m}$, though cells of $S$. marcescens Nima were twice as large. The colonies were typical of Serratia. Pigment, which differed from that of $S$. marcescens Nima, was produced at $37^{\circ} \mathrm{C}$ but not at $40^{\circ} \mathrm{C}$. Abundant creamy growth occurred on potato dextrose agar. In motility test agar cultures, abundant growth occurred both aerobically and anaerobically, but pigment was only produced aerobically. The strain was actively motile. Both RW3 and Nima produced phospholipase. Abundant growth was produced by the isolate on medium containing $\alpha$-cellulose, microcrystalline cellulose or CM-cellulose as the carbon source. CM-cellulose gel was slowly hydrolysed (Table I). Neither the isolate nor the Nima strain required vitamins or amino acids for growth.

Serratia marcescens RW3 fermented galactose, but $S$. marcescens Nima did not. Sorbitol and inositol were fermented by Nima, but not by Rw3 (Table 2). Acetic acid was utilized by RW3 as sole carbon source, but not by Nima. Both malonic and $\alpha$-ketoglutaric acids were utilized as sole carbon sources by Nima but not by RW3 (Table 4).

Since the colours of the colonies were different, the pigments produced by the strains were analysed. Both strains produced prodigiosin or a prodigiosin-like pigment and diffusible water-soluble pigments. Purified prodigiosins from both strains had identical spectra in 


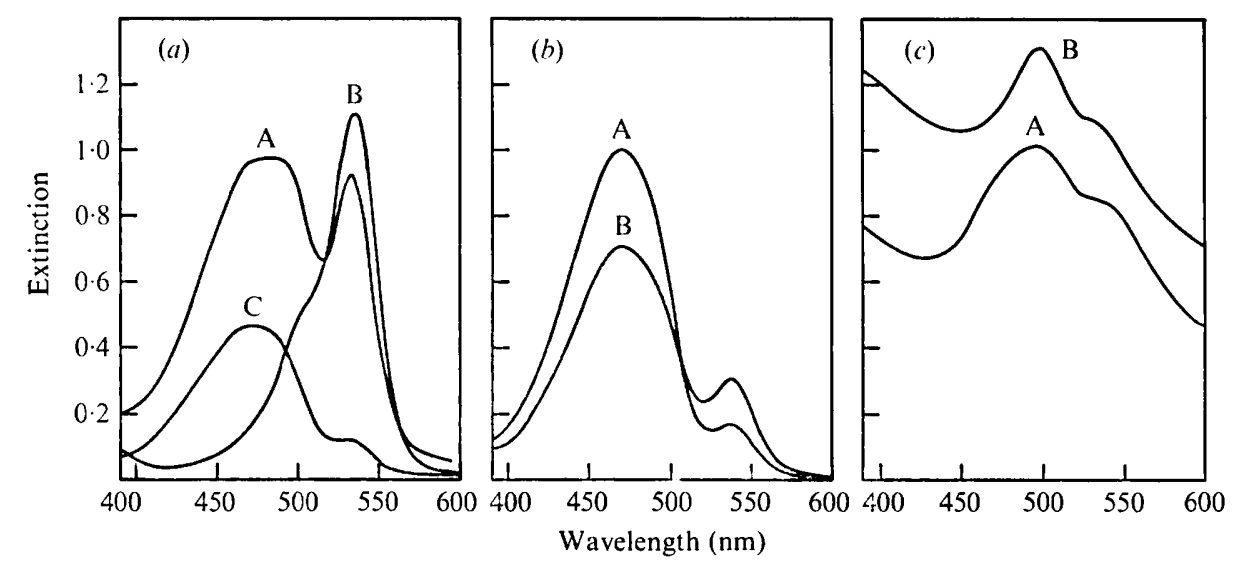

Fig. I (a). Absorption spectra of purified prodigiosin from $S$. marcescens $\mathrm{RW}_{3}: \mathrm{A}$, in $85 \%(\mathrm{v} / \mathrm{v})$ ethanol solution; B, in acid (two drops of glacial acetic acid); and C, at $\mathrm{pH} 10$.

(b). Absorption spectra of absolute ethanol extracts of S. marcescens Nima (A) and S. marcescens RW3 (B).

(c). Absorption spectra of aqueous suspensions of intact cells of $S$. marcescens Nima (A) and S. marcescens RW3 (B).

alkaline, neutral or acidic solutions (Fig. I $a$ ). The alcohol-soluble pigment(s) from intact cells were similar but not identical; that from $S$. marcescens $\mathrm{RW}_{3}$ had a higher extinction at $536 \mathrm{~nm}$ but a lower extinction at $468 \mathrm{~nm}$ than that of $S$. marcescens Nima (Fig. I $b$ ). The absorption spectra of water-soluble pigments from both strains were identical but more pigment was extracted from strain Nima. Aqueous suspensions of RW3 or Nima cells both had absorption maxima at $490 \mathrm{~nm}$ and shoulders at $530 \mathrm{~nm}$ but had a different minimum in the 430 to $450 \mathrm{~nm}$ region (Fig. I c). Water-soluble pigments had absorption spectra identical to that of the cells. Further purification of the pigments is necessary to establish if they are identical.

Organism Rw6 was typical of the genus Arthrobacter. The data were insufficient to allow species identification. Cells underwent a typical change from cocci to rods. Cocci were $0 \cdot 75$ to $\mathrm{I} \cdot 0 \mu \mathrm{m}$ diam. in cultures incubated for 2 days or longer; the size gradually increased during further incubation. When these cocci were transferred to fresh medium, they elongated at one or more positions to form rods or $Y$-shaped cells. The rods were actively motile and 0.5 by $2.5 \pm 2.0 \mu \mathrm{m}$. The cocci were usually found in pairs. Growth was slow in TSB and other culture media. Colonies on TSA were circular, $2 \mathrm{~mm}$ diam., convex, entire-edged, golden and shiny after 5 days' incubation at $30^{\circ} \mathrm{C}$. Growth on TSA slants was filiform, flat, yellow and glistening. In TSB, the broth was slightly turbid with a definite sediment. Growth did not occur on potato dextrose agar. Abundant growth occurred on mineral salts agar containing I \% (w/v) $\alpha$-cellulose or CM-cellulose as the carbon source. The nutritional requirements of this strain were complex since growth did not occur in the mineral salts medium containing both Casamino acids and yeast extract but did occur in the control tube of TSB.

\section{DISCUSSION}

Both strains of Bacillus cereus grew well on $\alpha$-cellulose agar and though strain RWI grew well on CM-cellulose agar it grew poorly on microcrystalline cellulose agar unless 
yeast extract was added. The presence of a CM-cellulase was demonstrated in RWI but not in RW7 by the hydrolysis of a CM-cellulose gel. Growth on the $\alpha$-cellulose agar does not necessarily demonstrate the presence of enzymes capable of solubilizing $\alpha$-cellulose, as growth may have been due to impurities in the medium, though the $\alpha$-cellulose used had a stated purity of $99.5 \%$. Growth of RWI on $\alpha$-cellulose agar but not on the CM-cellulose agar is further confused by the requirement of RWI for either amino acids or yeast extract. This requirement is the most likely reason for the lack of growth of RWI on $\alpha$-cellulose as the sole carbon source.

Though both RWI and RW7 were identified as Bacillus cereus using standard keys (Gibson \& Gordon, 1974; Wolf \& Barker, 1968), they were not identical; biochemical differences included DNA hydrolysis by RW7 but not RWI, possession of L-arginine decarboxylase by RWI which fermented cellobiose and starch, and assimilated malic or fumaric acid as a sole carbon source.

Serratia marcescens RW3 was unusual in producing abundant growth on cellulosic media ranging from mesquite wood (Thayer et al., I975) to CM-cellulose. It was highly fermentative but did not ferment cellobiose. Both RW3 and Nima strains assimilated most of the organic acids investigated and utilized several as their sole carbon source. Evidence was presented in a previous paper for the presence of cellulase active against microcrystalline cellulose and presumptive evidence for the hydrolysis of lignin (Thayer et al., 1975).

Arthrobacter sp. Rw6 grew well on $\alpha$-cellulose and may be significant for this reason. Because its growth rate was slow, it probably would not provide protein for the host termite but it might provide enzymes which would interact with those from other organisms.

This study has not clarified the role of the bacteria associated with the flagellate protozoans of termite hind-guts. The methods which were chosen for cultivation allowed the growth of only the free living and relatively non-fastidious bacterial species. Hypermastigote flagellates were observed in the gut contents along with their associated spirochaetes. Cleveland \& Grimstone (1964) described the fine structure of the flagellate Mixotricha paradoxa and its associated micro-organisms.

Relatively few studies have been made of the bacteria associated with the termite and only a few obtained evidence for any cellulolytic activity. Dickman (I93I) found many different cellulose digesting organisms in the nest walls but not in the intestinal contents of Reticulitermes flavipes. Beckwith \& Rose (1929) reported cellulose digestion by bacteria isolated from Reticulitermes hesperus and several other species. These workers incubated their cultures aerobically as was done in this study. Hungate (1946) isolated an anaerobic cellulosedecomposing actinomycete, Micromonospora propionici, from the crushed alimentary tract of a worker termite, Amitermes minimus, but as it grew extremely slowly its importance to the digestion of cellulose by the termite was discounted. Schmidt (1956) described bacterial vacuoles of protozoa isolated from the hind-gut of Reticulitermes lucifregus and attributed the digestion of wood to the bacteria. Kovoor (I968) found pockets containing bacteria which she designated as a fermentation chamber in the hind-gut of Microcerotermes edantatus. The species isolated from the hind-gut were unable to degrade filter paper strips. All, however, grew rapidly on media containing ground mesquite wood as the sole carbon source and produced cellulases. These strains may interact with the cellobiase-producing bacteria in the hind-gut to achieve rapid wood digestion.

The author wishes to thank R. Winegar who performed the initial isolations from the hind-gut, and C. Lindner, J. V. Perez, and K. R. Schulze for their technical assistance. The author acknowledges the culture of Serratia marcescens Nima provided by R. P. Williams. 
This investigation was supported by funds from the Brush Control and Range Improvement Association, the Dodge Jones Foundation, and the State of Texas.

\section{REFERENCES}

ANDERson, L. R. (1930). Peroxidase in relation to bacterial growth with special reference to the influenza bacillus. Journal of Bacteriology 20, 37I-379.

BeCKWITH, T. D. \& Rose, E. J. (I929). Cellulose digestion by organisms from the termite gut. Proceedings of the Society for Experimental Biology and Medicine 27, 4-6.

Bergey's Manual of Determinative Bacteriology, 8th edn (1974). Edited by R. E. Buchanan and N. E. Gibbons. Baltimore: Williams and Wilkins.

Cleveland, L. R. \& Grimstone, A. V. (1964). The fine structure of the flagellate Mixotricha paradoxa and its associated microorganisms. Proceedings of the Royal Society B 159, 668-686.

Dickman, A. (193I). Studies on the intestinal flora of termites with reference to their ability to digest cellulose. Biological Bulletin. Marine Biological Laboratory, Woods Hole, Mass. 6r, 85-92.

Gibson, T. \& GoRdon, R. E. (1974). Genus I. Bacillus Cohn I872. In Bergey's Manual of Determinative Bacteriology, 8th edn, p. 529. Edited by R. E. Buchanan and N. E. Gibbons. Baltimore: Williams and Wilkins.

Gordon, R. E., Haynes, W. C. \& Pang, C. H.-N. (1973). The Genus Bacillus. Agricultural handbookno. 427. Washington, D.C.: Agricultural Research Services, United States Department of Agriculture.

Holding, A. J. \& ColleE, J. G. (197I). Routine biochemical tests. In Methods in Microbiology, vol. 6A, pp. 2-32. Edited by J. R. Norris and D. W. Ribbons. London: Academic.

HubBaRd, R. \& Rimington, C. (1950). The biosynthesis of prodigiosin, the tripyrrylmethene pigment from Bacillus prodigiosus (Serratia marcescens). Biochemical Journal 46, 220-225.

Hugh, R. \& Leifson, E. (1953). The taxonomic significance of fermentative versus oxidative metabolism of carbohydrates by various Gram-negative bacteria. Journal of Bacteriology 66, 24-26.

HuNGATE, R. E. (1946). Studies on cellulose fermentation. II. An anaerobic cellulose decomposing actinomycete, Micromonospora propionici n.sp. Journal of Bacteriology 5I, 5I-56.

KNight, B. C. J. G. \& Proom, H. (I950). A comparative survey of the nutrition and physiology of mesophilic species in the genus Bacillus. Journal of General Microbiology 4, 508-538.

Kovoor, J. (1968). L'intestin d'un termite superieur (Microcerotermes edantatus Was., Amitermitinae). Histophysiologie et flore bactérienne symbiotique. Bulletin Biologique de la France et de la Belgique ro2, 46-84.

LeIFson, E. (I95I). Staining, shape and arrangement of bacterial flagella. Journal of Bacteriology 62, 377389.

SAKAZAKI, R. (1974). Genus IX. Serratia Bizio 1823. In Bergey's Manual of Determinative Bacteriology, 8th edn, p. 326. Edited by R. E. Buchanan and N. E. Gibbons. Baltimore: Williams and Wilkins.

SchmidT, H. (1956). Studien an darmbewohnenden Flagellaten der Termiten. II. Mitteilung. Holzteilchen als Zelleinschlüsse und Nahrung bei Trichonympha and Joenia. Zeitschrift für Parasitenkunde 17, 269275.

Shimwell, J. L., CARR, J. G. \& RHodes, M. C. (1960). Differentiation of Acetomonas and Pseudomonas. Journal of General Micribiology 23, 283-286.

SKeRMAN, V. B. D. (1967). A Guide to the Identification of the Genera of Bacteria, 2nd edn. Baltimore: Williams and Wilkins.

Smith, N. R., Gordon, R. E. \& Clark, F. E. (1952). Aerobic Sporeforming Bacteria. Agricultural monograph no. 16. Washington, D.C.: United States Department of Agriculture.

Stanier, R. Y., Palleroni, N. J. \& Doudoroff, M. (I966). The aerobic pseudomonads: a taxonomic study. Journal of General Microbiology 43, I59-27I.

Thayer, D. W., YANG, S. P., Key, A. B., YANG, H. H. \& Barker, J. W. (1975). Production of cattle feed by the growth of bacteria on mesquite wood. Developments in Industrial Microbiology 16, 465-474.

Williams, R. P., GotT, C. L., QADRI, S. M. H. \& ScotT, R. H. (I97I). Influence of temperature of incubation and type of growth medium upon pigmentation in Serratia marcescens. Journal of Bacteriology ro6, 438-443.

WOLF, J. \& BARKER, A. N. (1968). The genus Bacillus: aids to the identification of its species. In Identification Methods for Microbiologists, part B. Edited by B. M. Gibbs and D. A. Shapton. London: Academic.

YAMADA, K. \& Komagata, K. (1972). Taxonomic studies on coryneform bacteria. IV. Morphological, cultural, biochemical, and physiological characteristics. Journal of General and Applied Microbiology 18, 399-416. 